\section{International Scientific Journal}

\section{Theoretical \& Applied Science}

p-ISSN: 2308-4944 (print) $\quad$ e-ISSN: 2409-0085 (online)

Year: 2015 Issue: 09 Volume: 29

Published: $30.09 .2015 \quad$ http://T-Science.org
Ali J. Dawood

Assistant Lecturer

Aircraft Engineering Branch

Mechanical Engineering Department

Baghdad University of Technology,

Iraq

ali_jabbar_dawood@uotechnology.edu.iq

SECTION 31. Economic research, finance,

innovation, risk management.

\title{
USE LOW COST CARRIER STRATEGY AS SOLUTION TO REDUCE AIRCRAFT TICKET PRICE IN IRAQ
}

Abstract: Air transport is one of the most important sectors growing in Iraq, especially after 2003 and the removal of all restrictions that were imposed for the movement of people prior to this date also air transport are predicted to take advanced place in Iraqi economic. Iraq has the magnificent site in the heart of Middle East and this region which connecting Continents of the world. Iraq has seen a significant growth in the number of airports across his territory also increase of international airlines that work in Iraq but high prices of airline tickets is one of the most prominent problems of the aviation sector in Iraq compared to other airlines in the world prices for same distances, Knowing that most of the companies trying to lower the price in order to attract larger numbers of travelers.

Using of low cost carrier is one of the best solutions that ensure reduced ticket prices and this strategy has succeeded in a lot of areas in the world

Key words: Low cost carrier, Airline, Airplane, Iraqi Airways, Iraq, Baghdad.

Language: English

Citation: Dawood AJ (2015) USE LOW COST CARRIER STRATEGY AS SOLUTION TO REDUCE AIRCRAFT TICKET PRICE IN IRAQ. ISJ Theoretical \& Applied Science 09 (29): 1-6.

Soi: http://s-o-i.org/1.1/TAS-09-29-1 Doi: crossef http://dx.doi.org/10.15863/TAS.2015.09.29.1

\section{Introduction}

American airline (Pacific Southwest airlines company was founded in Texas 1967) consider the first airline started the concept of low cost carrier back to 1981, many airline in America followed this strategy, this idea take more time to apply in Europe its start in 1991, start with Ryan Air and Easy Jet (formed in 1995). We can notes the different in time between America and Europe to apply this strategy because America is one country with large area but
Europe different countries and its take time to lifting of restrictions between countries.

In Middle East the progress not satisfy the ambition due to the restrictions between Arab countries and their neighbors in aviation regulation except Arabian Gulf countries which they have Cooperation in this field also State of United Arab Emirates has been achieved a good progress in LLC.

LLC Now has global spread and we can see that in Table 1 the number of LLC operating in different countries. [1][2][3][4]

LLC countries operating - 2005 .

Table 1

Lecountr

\begin{tabular}{|c||c||}
\hline Country & No. of LLC \\
\hline \hline Asian countries & 31 \\
\hline \hline European countries & 41 \\
\hline \hline UK & 12 \\
\hline \hline USA & 12 \\
\hline \hline Canada & 5 \\
\hline \hline Pacific countries & 5 \\
\hline South America & 4 \\
\hline
\end{tabular}




\begin{tabular}{|c|c|c|c|c|c|}
\hline Impact Factor: & $\begin{array}{l}\text { ISRA (India) } \\
\text { ISI (Dubai, UAE } \\
\text { GIF (Australia) } \\
\text { JIF }\end{array}$ & $\begin{array}{r}=1.344 \\
=0.829 \\
=0.356 \\
=1.500\end{array}$ & $\begin{array}{l}\text { SIS (USA) = } \\
\text { PUHЦ (Russia) = } \\
\text { ESJI (KZ) = } \\
\text { SJIF (Morocco) }\end{array}$ & $\begin{array}{l}=0.912 \\
=0.179 \\
=1.042 \\
=2.031\end{array}$ & ICV (Poland) \\
\hline
\end{tabular}

\begin{tabular}{|c||c||}
\hline countries & \\
\hline \hline African countries & 1 \\
\hline \hline Total & 111 \\
\hline
\end{tabular}

\section{Theory of LCC}

As we say before, the idea of low cost carrier back to 1980 so there are a lot of problem faced the idea and many solution put for improvement it, we will not go to further the theory but we will explain the basic of theory.
At first we can see Fig.1 which represents the operating expenses of the airline industry and we can decide which section we can work on it to minimize the cost of ticket.

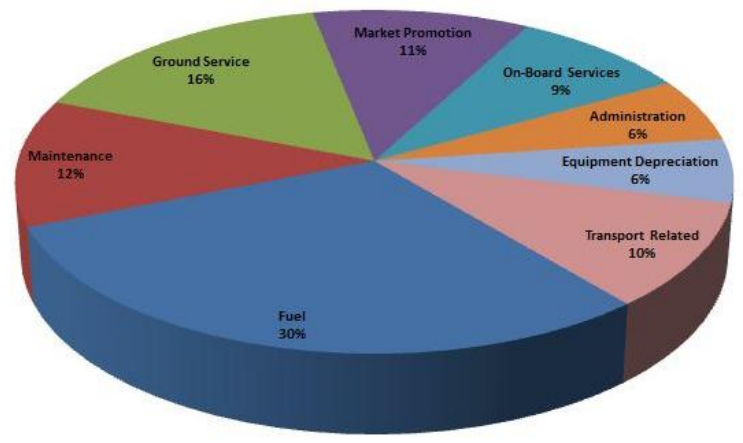

Figure 1 - The various type of operating expenses of an airline [2].

Table 2 shows which strategic measures lead to the reduction in unit costs.

Cost distribution of LCC on short- haul flight in relation to traditional operators.

Table 2

\begin{tabular}{|l||c||c||}
\hline \multicolumn{1}{|l||}{} & Cost reduction (\%) & Cost per seat \\
\hline \hline Traditional scheduled airline & & 100 \\
\hline \hline Low cost carrier & & \\
\hline \hline Operating advantage: & & 84 \\
\hline \hline High seating density & -16 & 82 \\
\hline Higher aircraft utilization & -2 & 79 \\
\hline Lower flight and cabin crew costs & -3 & 75 \\
\hline Use cheaper secondary airports & -2 & 73 \\
\hline Outsourcing maintenance/ single aircraft type & & 66 \\
\hline Product/ service features: & -7 & 61 \\
\hline Minimal station costs and outsourced handling & -5 & 55 \\
\hline No free in-flight catering, fever passenger services & & 52 \\
\hline Difference in distribution: & -6 & 49 \\
\hline No agents or GDS commissions & -3 & 49 \\
\hline Reduced sales/ reservation costs & -3 & \\
\hline Other advantage: & & \\
\hline \hline Smaller administration and fewer staff/offices & & \\
\hline Low-cost compared to traditional airline & & \\
\hline
\end{tabular}

Source Doganis (2007) [5]

\section{Principles of operation}

1- One type of passenger class (there are no first or business class)
2- Fleet consists of one type of airplane (such as Airbus A320 or Boeing B737). In this case pilots and the crew of airplane can operate in any airplane in the fleet because it's one type and that 


\begin{tabular}{|c|c|c|c|c|c|c|}
\hline Impact Factor: & $\begin{array}{l}\text { ISRA (India) } \\
\text { ISI (Dubai, UAF } \\
\text { GIF (Australia) } \\
\text { JIF }\end{array}$ & $\begin{array}{l}=1.344 \\
=0.829 \\
=0.356 \\
=1.500\end{array}$ & $\begin{array}{l}\text { SIS (USA) } \\
\text { PИНЦ (Russia) } \\
\text { ESJI (KZ) } \\
\text { SJIF (Morocco) }\end{array}$ & $\begin{array}{l}=0.912 \\
=0.179 \\
=1.042 \\
=\mathbf{2 . 0 3 1}\end{array}$ & ICV (Poland) & $=6.630$ \\
\hline
\end{tabular}

will save many of training pilots to different airplane.

3- Cheap fees, increase with services. LCC don't offer drink or food but you can buy it on airplane the weight of baggage are limited and you will pay for additional weight.

4- Unreserved seating or free seating, which contribute in minimize the operation cost, it embolden to buy the ticket earlier.

5- Using secondary airports. The advantage of using secondary airports it's less busy than the main airports and the cost of services will be cheap.

6- Simplified routes and short Haul flight with fast turnaround time. (Less than $1500 \mathrm{~km}$ ) and with these distance we get low operating costs per passenger required.

7- Electronic ticket, selling directly to customers to minimize the add cost to the ticket by commissions of travel agents. LCC using internet or call center and avoid computer reservation fees. [2] [5] [6]

\section{Iraq aviation: status and possibility}

The Iraq Civil Aviation Authority (ICAA)
Is the agency responsible for Iraq's obligations under the provisions of Annex 9 (Facilitation) of the Chicago Convention. The ICAA is responsible for coordinating with other Iraq agencies for the development and implementation of policy and coordination of ICAO matters. The (ICAA) is the specialist aviation regulator in Iraq. Its activities include airspace policy, flight permissions, safety regulations and economical regulations. New carriers wishing to operate in Iraq must receive full approval from ICAA prior to flight commencement. [7]

\section{Approved Airports by (ICAA)}

Civilian aircraft flying into or out of Iraqi territory shall only be permitted to make their first landing and final departure from an approved International Airport in order to complete required Customs and Immigration clearance. The current ICAA approved International Airports are:[7]

$>$ Baghdad International.

Erbil International.

$>$ Sulaymaniyah International.

$>$ Basra International.

$>$ Al Najaf Al-Ashraf International.

In Fig. 2 we can see the location of these airports in Iraq map.

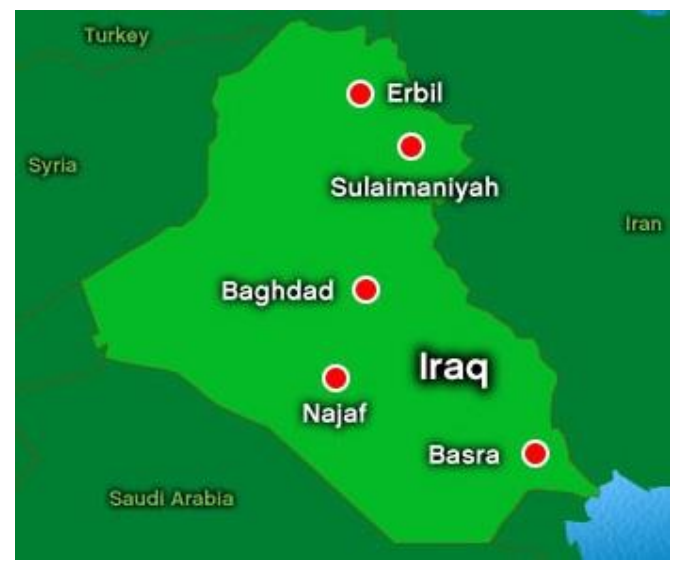

Figure 2 - The Iraq main airports.

\section{Iraqi Airways companies}

In Iraq there is one national airline company called "Iraqi Airways" was founded in 1945 and we can consider it the first airline company in the Middle East. It was used at the beginning of the British and Soviet-made airplane. In the sixties Iraqi Airways was quick to modernize, buying new jet airplane, these jets allowed Iraqi Airways to increase service across the Middle East, to Africa and Europe. In the seventies the United States has allowed Iraqi Airways planes using John F. Kennedy International Airport in New York, and because of that, it needed a bigger jet, so they buy Boeing 707, 747 jets. Fig. 3 show as the Iraqi Airways destinations. 


\begin{tabular}{|c|c|c|c|c|c|c|}
\hline Impact Factor: & $\begin{array}{l}\text { ISRA (India) } \\
\text { ISI (Dubai, UAE } \\
\text { GIF (Australia) } \\
\text { JIF }\end{array}$ & $\begin{array}{l}=1.344 \\
=0.829 \\
=0.356 \\
=1.500\end{array}$ & $\begin{array}{l}\text { SIS (USA) } \\
\text { PИHЦ (Russia) } \\
\text { ESJI (KZ) } \\
\text { SJIF (Morocco) }\end{array}$ & $\begin{array}{l}=0.912 \\
=0.179 \\
=1.042 \\
=2.031\end{array}$ & ICV (Poland) & $=6.630$ \\
\hline
\end{tabular}

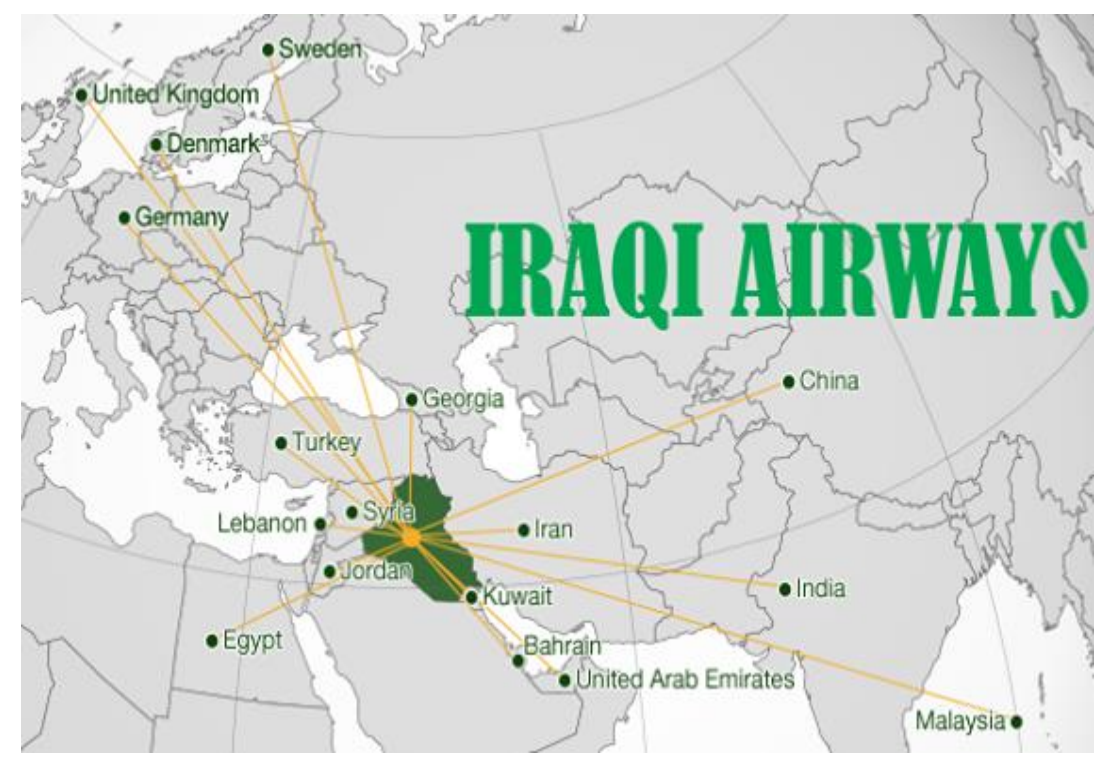

Figure 3 - Iraqi Airways destinations.

\section{Analyzing the case}

As we see, Iraqi Airways destinations to different places from different cities, in Table 3 we can see Airplane and passenger traffic in three Iraqi civil airports (Baghdad, Basra and Najaf) according to the report issued by the General Establishment of Civil Aviation for the period from 8-14 / 4/2015.

Table 3

Airplane and passenger traffic in Iraqi civil airports [8].

\begin{tabular}{|l||c|c|c||}
\hline \multicolumn{1}{|c|}{ Airport name } & Baghdad & Basra & Najaf \\
\hline \hline No. of incoming flights & 207 & 89 & 184 \\
\hline No. of passengers arriving & 19488 & 7279 & 21145 \\
\hline \hline No. of departing flights & 211 & 89 & 184 \\
\hline \hline No. of departing passengers & 23825 & 7430 & 25183 \\
\hline
\end{tabular}

To simplify we will choose Baghdad airport (the Capital airport) with three destinations that meet the low cost carrier demand and its important destination which is:

1- Baghdad - Erbil, flight time $53 \mathrm{~min}$, flight distance $321 \mathrm{~km}$, internal flight, and this route considered one of the most routes use especially in summer and in many times when the overland route be dangerous between the Middle and North of Iraq. If we compared the price of ticket between let say "Iraq Airways" and LCC in Europe for the same distance, the result in Table 4. 


\begin{tabular}{|c|c|c|c|c|c|c|}
\hline Impact Factor: & $\begin{array}{l}\text { ISRA (India) } \\
\text { ISI (Dubai, UAF } \\
\text { GIF (Australia) } \\
\text { JIF }\end{array}$ & $\begin{array}{r}=1.344 \\
=0.829 \\
=0.356 \\
=1.500\end{array}$ & $\begin{array}{l}\text { SIS (USA) } \\
\text { PИНЦ (Russia) } \\
\text { ESJI (KZ) } \\
\text { SJIF (Morocco) }\end{array}$ & $\begin{array}{l}=0.912 \\
=0.179 \\
=1.042 \\
=2.031\end{array}$ & ICV (Poland) & $=6.630$ \\
\hline
\end{tabular}

\section{Compared the price of ticket between different company [8] [10] [11].}

Table 4

\begin{tabular}{|c|c||c||c|}
\hline Departure city & Warsaw, Poland & Baghdad, Iraq & Madrid, Spain \\
\hline \hline Arrival city & Malmo, Sweden & Erbil, Iraq & Porto, Portugal \\
\hline Distance in km & 645 & 321 & 421 \\
\hline \hline Airways company & Wizz Air & Iraqi airways & Ryan Air \\
\hline Price in $\$$ & 22.49 & 100 & 17 \\
\hline
\end{tabular}

We measure the distance between the city according to Ref. [9] and we made the reservation to all company in the same date $19 / 08 / 2015$ for same for same departure day 01/10/2015, one way.

2- Baghdad - Dubai/ UAE, flight time 2 hr. 13 min, flight distance $1389 \mathrm{~km}$, External flight, and this route considered one of the most routes use in all year which connect Baghdad to Asia through Dubai. If we compared the price of ticket between let say "Iraq Airways" and LCC in Europe for the same distance, the result in Table 5 .

Table 5

\section{Compared the price of ticket between different company [8] [10] [11].}

\begin{tabular}{|c|c|c|c|}
\hline Departure city & Warsaw, Poland & Baghdad, Iraq & Warsaw, Poland \\
\hline Arrival city & Beauvais, France & Dubai, UAE & Beauvais, France \\
\hline Distance in $\mathrm{km}$ & 1362 & 1389 & 1362 \\
\hline Airways company & Wizz Air & Iraqi airways & Ryan Air \\
\hline Price in $\$$ & 23 & 208 & 30 \\
\hline
\end{tabular}

We measure the distance between the city according to Ref. [9] and we made the reservation to all company in the same date 19/08/2015 for same for same departure day $01 / 10 / 2015$, one way

3- Baghdad - Istanbul / Turkey, flight time $2 \mathrm{hr}$. $30 \mathrm{~min}$, flight distance $1611 \mathrm{~km}$, External flight, and this route considered one of the most routes use during the all year especially in summer connect the Iraqi capital with Istanbul which consider the gate to the rest of the world. If we compared the price of ticket between let say "Iraq Airways" and LCC in Europe for the same distance, the result in Table 6.

\section{Compared the price of ticket between different company[8] [10] [11].}

Table 6

\begin{tabular}{|c|c|c|c|}
\hline Departure city & Warsaw, Poland & Baghdad, Iraq & Warsaw, Poland \\
\hline Arrival city & Barcelona, Spain & Istanbul, Turkey & Barcelona, Spain \\
\hline Distance in $\mathrm{km}$ & 1877 & 1611 & 1877 \\
\hline Airways company & Wizz Air & Iraqi airways & Ryan Air \\
\hline Price in $\$$ & 82.29 & 360 & 95 \\
\hline
\end{tabular}

We measure the distance between the city according to Ref. [9] and we made the reservation to all company in the same date 19/08/2015 for same for same departure day $01 / 10 / 2015$, one way 


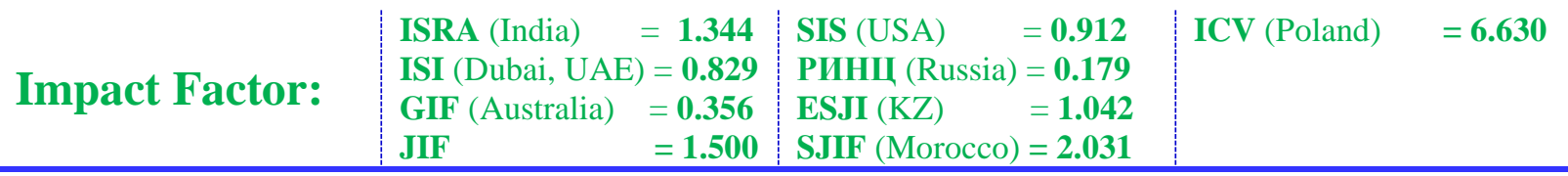

\section{Discussion and Conclusion}

As we see in the Tables, there are big difference between the price of ordinary airline company represented by "Iraqi Airways" in our paper and low cost carrier, Although "Iraqi Airways" considered one of the cheap airlines company in the area due to nonprofessional service that provide it and "Iraqi Airways" have problem in planning, organization due to unstable situation in Iraq that made the passenger almost from Iraq only, in our simulation we based on the distance of flight as a criteria and we know this approach give us $80 \%$ from the real situation but in total show us the huge reduce in price of ticket. Now we will list the strengths and weaknesses in Iraqi situation.

\section{Strengths}

Iraq has great financial ability, cheap efficient workers, special location in the Middle East which consider the link between continental, possibility of supply the fuel with motivational price "Iraq is one of rich oil country so it's not affected too much with increase the oil price", satisfied aviation structure and he liberated from all constraints which Imposed on him before 2003 so he must organized many things in aviation and investment and create a safe environment to attract the investor from out and inside Iraq.

\section{Weaknesses}

One off the most weaknesses is the non-stable situation which effect on the investment in Iraq, administrative corruption and bureaucracy, failure proper planning for aviation sector and nonutilization of International expertise.

At the end, LCC strategy proved around the world but it's only succeed with good planning to all process with high accuracy, and increase the number of a working airlines has great benefit to variety the services which present to passenger.

\section{References:}

1. Stephen Shaw (2012) Airline Marketing and Management, 2012, seventh edition, pp.281.

2. PS Senguttuvan (2006) Fundamentals of Air Transport Management, First Edition, New Delhi, 2006, pp.97,98,101,102.

3. Vanessa Blaha (2015) Low Cost Carriers Evolution, Strategies and Performance.

4. Sven Gross, Alexander Schröder (2015) Handbook of Low Cost Airlines: Strategies, Business Processes and Market Environment, pp.28.

5. Andrija Vidović1, Igor Štimac, Damir Vince (2013) development of business models of lowcost airlines, International Journal for Traffic and Transport Engineering, 2013.
6. Alessandro Cento (2015) The Airline Industry: Challenges in the 21st Century, pp.19.

7. (2015) The Iraq Civil Aviation Authority (ICAA) Available: http://www.iraqcaa.com/ (Accessed: 20.08.2015).

8. (2015) Iraqi airways company, Available: http://www.iraqiairways.com.iq/ (Accessed: 20.08.2015).

9. (2015)

Available: http://www.distancesfrom.com/ (Accessed: 20.08.2015).

10. (2015) Available: http://www.ryanair.com/ (Accessed: 20.08.2015).

11. (2015) Available: https://wizzair.com/enGB/FlightSearch (Accessed: 20.08.2015). 